University of Nebraska - Lincoln

DigitalCommons@University of Nebraska - Lincoln

1997

\title{
Divergent Selection for Heat Loss in Mice: II. Correlated Responses in Feed Intake, Body Mass, Body Composition, and Number Born Through Fifteen Generations
}

\author{
Merlyn K. Nielsen \\ University of Nebraska-Lincoln, mnielsen1@unl.edu \\ B. A. Freking \\ University of Nebraska-Lincoln, brad.freking@ars.usda.gov \\ L. D. Jones \\ University of Nebraska-Lincoln
}

S. M. Nelson

lowa State University

T. L. Vorderstrasse

Case Western Reserve University

See next page for additional authors

Follow this and additional works at: https://digitalcommons.unl.edu/animalscifacpub

Part of the Animal Sciences Commons

Nielsen, Merlyn K.; Freking, B. A.; Jones, L. D.; Nelson, S. M.; Vorderstrasse, T. L.; and Hussey, B. A., "Divergent Selection for Heat Loss in Mice: II. Correlated Responses in Feed Intake, Body Mass, Body Composition, and Number Born Through Fifteen Generations" (1997). Faculty Papers and Publications in Animal Science. 504.

https://digitalcommons.unl.edu/animalscifacpub/504

This Article is brought to you for free and open access by the Animal Science Department at DigitalCommons@University of Nebraska - Lincoln. It has been accepted for inclusion in Faculty Papers and Publications in Animal Science by an authorized administrator of DigitalCommons@University of Nebraska - Lincoln. 
Authors

Merlyn K. Nielsen, B. A. Freking, L. D. Jones, S. M. Nelson, T. L. Vorderstrasse, and B. A. Hussey 


\title{
Divergent Selection for Heat Loss in Mice: II. Correlated Responses in Feed Intake, Body Mass, Body Composition, and Number Born Through Fifteen Generations ${ }^{1,2}$
}

\author{
M. K. Nielsen3, B. A. Freking, L. D. J ones, S. M. Nelson4, \\ T. L. Vorderstrasse, ${ }^{5}$ and B. A. Hussey6
}

University of Nebraska-Lincoln, Lincoln 68583-0908

\begin{abstract}
Divergent selection for heat loss $\left(\mathrm{kcal} \cdot \mathrm{kg}^{-} \cdot 75 \cdot \mathrm{d}^{-1}\right)$, measured in 9- to 11 -wk-old male mice, was conducted for 15 generations. Selection for high $(\mathrm{MH})$ and low $(\mathrm{ML})$ heat loss and unselected control (MC) occurred in each of three replicates for a total of nine unique lines. Feed intake in males was measured during Generations 9 through 15. Body mass at commencement of mating in females and at time of measurement of heat loss in males was recorded. Body fat percentage at $12 \mathrm{wk}$ for animals of Generations 6, 10, and 14 was predicted as a function of electrical conductivity and body mass. Litter size was recorded for all generations, and components of litter size were evaluated at Generation 11 in one replicate and Generation 12 in the other two repli-
\end{abstract}

cates. Feed intake changed in the same direction as heat loss for the MH and ML selections; at Generation 15 , the difference between $\mathrm{MH}$ and $\mathrm{ML}(\mathrm{P}<.002)$ was $20.6 \%$ of the MC mean. Body mass did not change with selection for heat loss. Differences in body fat percentage were not significant in earlier generations, but at Generation 14, MH and ML were significantly $(\mathrm{P}<.01)$ different with $\mathrm{MH}$ mice having the lowest fat percentage; MC was intermediate. Selection had a significant $(\mathrm{MH}$ vs $\mathrm{ML} ; \mathrm{P}<.01$ ) effect on litter size, causing an increase in $\mathrm{MH}$ and a decrease in $\mathrm{ML}$. This difference was explained by a difference $(P<.01)$ in ovulation rate. There was no asymmetry of response in feed intake, fatness, litter size, or number of ovulations.

Key Words: Mice, Heat Loss, Selection, Feed Intake, Body Composition, Litter Size

\section{Introduction}

Genetic selection to reduce feed intake, especially that needed to meet maintenance, may be one avenue for livestock industries to reduce costs of livestock

\footnotetext{
${ }^{1}$ Published as paper no. 11606, J ournal Ser., Nebraska Agric. Res. Div., Univ. of Nebraska, Lincoln 68583-0908.

${ }^{2} \mathrm{Help}$ with data collection and animal management by J. D. Hauptman, E.L.A. Ribeiro, and several laboratory assistants, and suggestions and counsel from G. E. Dickerson, R. A. Britton, T. G. J enkins, C. L. Ferrell, K. A. Leymaster, P. S. Miller, and S. M. J ones are gratefully appreciated.

${ }^{3}$ To whom correspondence should be addressed: A218 Animal Science.

${ }^{4}$ Current address: College of Vet. Med., I owa State Univ., Ames, IA 50011.

${ }^{5}$ Supported by Howard Hughes Medical Institute grant through Nebraska Wesleyan Univ., Lincoln, NE. Current address: College of Medicine, Case Western Reserve Univ., Cleveland, OH 44106. TX.

${ }^{6}$ Current address: College of Liberal Arts, Univ. of Dallas, Dallas,

Received J uly 31, 1996.

Accepted J anuary 9, 1997.
}

production. Although direct response from such selection is desired, possible correlated responses to selection to reduce energy intake that occur in various other characteristics expressed during the animal life cycle may or may not be favorable. For example, reducing feed intake through selection may also produce a correlated increase or decrease in reproductive performance, growth, or body fatness.

We performed selection during 15 generations for increased and decreased heat production/loss in mature mice. Total heat loss was used as an indicator trait for maintenance energy. Energy used for maintenance is lost as heat if animals remain homeothermic. Heat loss was measured over a single 15-h period using direct calorimetry. Realized responses in heat production after 15 generations of selection and the realized heritability are presented in a companion report (Nielsen et al., 1997). The objectives of this research were to measure the correlated responses in feed intake, body mass, body composition, and litter size at birth and its components that have accompanied selection for heat loss. 


\section{Materials and Methods}

Experimental Animals. The base population, description of selection criteria and lines, and direct response to selection for heat loss are presented by Nielsen et al. (1997). There were three criteria for selection: $\mathbf{M H}=$ selection for high heat loss $\left(\mathrm{kcal} \cdot \mathrm{kg}^{-} .75 \cdot \mathrm{d}^{-1}\right), \mathbf{M L}=$ selection for low heat loss, and MC = no intentional selection. Three replicates of selection using three criteria for choosing breeder animals gave rise to nine unique lines. Within a replicate, the $M H, M L$, and $M C$ selection lines all had the same grandparents in establishing the base generation.

Breeder males and females were placed in mating cages at $12 \mathrm{wk}$ of age and litters were produced at 15 wk. For the selection process, only one parity was produced from breeders. The three replicates were separated by a 5 -wk interval between the same point in the life cycle.

Measurement of Traits. Feed intake was measured in each line during Generations 9 through 15. Feed intake was recorded in males only during a 3-wk period starting at approximately $8 \mathrm{wk}$ of age. The mice were in cages of two to six (usually five) animals, and they had ad libitum access to pelleted feed (Teklad diet 8604: $24 \%$ crude protein, $4 \%$ crude fat, $4.5 \%$ crude fiber, and $3.93 \mathrm{kcal} / \mathrm{g}$ gross energy) from hanging feed baskets. Total feed consumed during weekly periods was summed across all cages in a line. Body weights at the first and last days of the period of feed collection were recorded and averaged. The average weight (grams) was transformed to a metabolic weight $\left(\mathrm{kg} \cdot{ }^{75}\right)$, multiplied by the number of mice measured in the line and by 21 (number of days in the period) and then divided into the total feed consumed to yield average grams per metabolic weight per day.

Body mass of males was recorded on all males that had a heat measurement. Age at measurement, for all generations except Generation 0, ranged from 9 to 11 wk, but the average was the same for all lines, and no adjustment was made for age. Because our cal orimetry equipment was not ready for use when Generation 0 animals were 9 to 11 wk, we delayed measurement until 20 to 22 wk. For Generations 6, 10, and 15, all males in all lines had this measurement. The number of observations per line ranged from 72 to 80 . During the other generations, only a sample of males from the MC lines had heat and body mass recorded; numbers recorded in these generations ranged from 20 to 35 .

Body mass was recorded for all females entering mating cages as they were transferred to these cages; the exception was Generation 0 when no female weights were taken. Numbers per generation were 36 for $\mathrm{MH}$ and $\mathrm{ML}$ selection lines and 34 for the $\mathrm{MC}$ lines. Although there was some variability in age at time of measurement, females averaged the same ( 12 wk) across lines and no adjustment was made.
Body fatness was predicted by using electrical conductivity and body mass. All males in all lines of Generation 6 ( $n$ ranged from 63 to 78 per line, total of $644)$, three males and two females from each litter of Generation 10 ( $n$ was 48 males and 32 females per line, total of 720), and two males from each litter of Generation 14 ( $n$ was 32 per line, total of 288) were measured.

Electrical conductivity was measured with commercially available equipment (EM-SCAN, model SA-2, Springfield, IL). Before any of the mice were measured in this study, two replicates of samples of 40 mice ( 20 males and 20 females in each replicate, hence 80 mice total) were measured for electrical conductivity and body mass and then killed. Mice in these samples were drawn from the selection lines and were at the same ages and weights as those animals subsequently evaluated. Carcasses were then freeze-dried, and lipids were extracted with circulating ether through a soxhlet apparatus. Nonfat mass was calculated as the starting mass of the live animal minus the mass lost through the ether extraction.

Various regression models using the electrical conductivity with various transformations and body mass were evaluated for prediction of fat-free mass. In addition, the interaction with sex was evaluated. One regression model described the data very well, and there was no interaction with sex. The final model used to predict fat-free mass was:

$$
\begin{aligned}
& \text { predicted fat-free mass in grams }=-1.727 \\
& +1.5640 \times(\text { electrical conductivity reading) } .5 \\
& +.6247 \times \text { body mass in grams. }
\end{aligned}
$$

The variation explained by this model $\left(R^{2}\right)$ was $96 \%$ across both sexes. The fit of the data (fat-free mass, not fat percentage) is shown graphically in Figure 1.

Measurements of conductivity on each animal were performed until four similar readings were obtained. For measurement, an animal was put under general anesthesia (metafane inhaled) to avoid movement, placed in a supine position with the tail extended on the animal carrier made for the equipment, and then measured in the fixed mode. Fat percentage was calculated using predicted fat-free mass and body mass at time of measurement.

Litter size was recorded within $24 \mathrm{~h}$ after birth. Total number of live and fully formed dead pups was considered to be litter size born. During the growing phase following weaning and during breeding until females were transferred to littering cages, all animals had ad libitum access to pelleted feed (Teklad diet 8604). Following transfer to littering cages and through the nursing period, dams had ad libitum access to a different pelleted feed (Teklad diet 8626: $20 \%$ crude protein, $10 \%$ crude fat, $2 \%$ crude fiber, and $4.25 \mathrm{kcal} / \mathrm{g}$ gross energy).

Because we had observed a significant change in number born, the components of number born were 


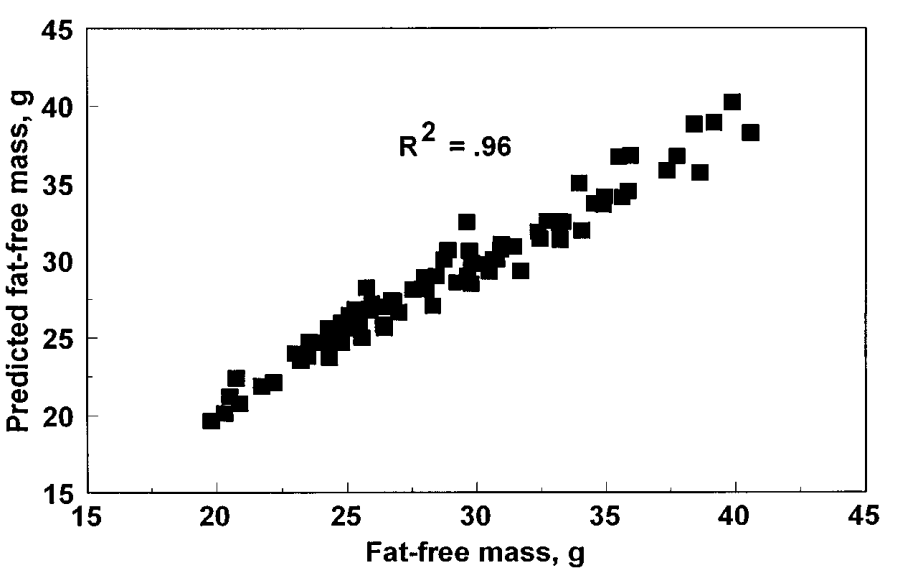

Figure 1. Relationship between fat-free mass predicted from body mass and electrical conductivity and actual fat-free mass.

examined with an intensive experiment in which data were collected from all lines consecutively in all three replicates but not at the same generation. Generation 11 of Replicate 3 and Generation 12 of Replicates 1 and 2 were measured. After females (plus some spare females that were always mated and pupped to serve as foster dams if needed) had produced their first litters to propagate the lines for the next generation, they were mated for a second parity at an average age of $19 \mathrm{wk}$. After weaning their first litters, females returned to ad libitum access to the lower-energy pelleted feed (Teklad diet 8604). Mating plugs were recorded. At $17 \mathrm{~d}$ of gestation, the females were euthanatized, the ovaries were excised, corpora lutea were counted (equated to number of ova shed), and number of viable fetuses was counted. Ova success was derived as the number of fetuses divided by the number of ovulations. Numbers of females measured per line ranged from 33 to 39, and the total was 329.

Statistical Analyses. Changes in mean body mass and number born over generations were evaluated by regressing the generation means on generation number. Regressions of measures of response $(M H-M L$,

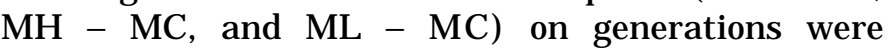
calculated within each replicate. For each type of regression, the average across replicates was then calculated. Standard errors for the average regressions were calculated empirically from the variation among estimates from the three replicates, thus accounting for variability due to drift. The average estimates were then tested for significance from zero using a $t$ distribution with 2 df.

The nine replicate-selection criteria means for feed intake, body mass, fat percentage, and litter size data for a given generation were analyzed for criteria differences using a model of replicate + criterion + replicate $\times$ criterion interaction (the error for criteria effects). The selection criteria means were compared using orthogonal contrasts of 1 ) $\mathrm{MH}$ vs ML to test for the effect of selection and 2) ( $M H+M L) / 2$ vs $M C$ to test for asymmetry of selection. The analysis of number born and its components was also expanded to include body mass of female as a covariate.

For characteristics with significant selection responses, estimates of genetic correlations were derived using the following relationship:

$$
r_{g_{H, k}}=\frac{C R_{k}}{i h_{H} h_{k} \sigma_{P_{k^{\prime}}}},
$$

where $r_{g_{H, k}}$ is the genetic correlation between heat loss and characteristic $k, C_{k}$ is the selection response in correlated trait $\mathrm{k}, \mathrm{i}$ is the cumulative intensity of selection, $h_{H}$ and $h_{k}$ are the square roots of heritabilities of heat loss and characteristic $k$, and $\sigma_{\mathrm{P}_{\mathrm{k}}}$ is the phenotypic standard deviation of characteristic $k$.

Using the mean responses across replicates, single estimates of the genetic correlation were made based on response for divergence $(\mathrm{MH}-\mathrm{ML})$ and upward $(\mathrm{MH}-\mathrm{MC})$ and downward $(\mathrm{ML}-\mathrm{MC})$ selections. Cumulative intensities were taken from the cumulative standardized selection differentials in this project reported by Nielsen et al. (1997). Heritabilities of heat loss for either divergence (.28), high (.31), or low (.26) selection were from Nielsen et al. (1997). Phenotypic standard deviations were $1.48 \%$ for fat percentage, $6.95 \mathrm{~g} \cdot \mathrm{kg}^{-} \cdot{ }^{.75} \cdot \mathrm{d}^{-1}$ for feed intake, and 2.68 for number born. Values for heritabilities of the correlated characteristics had to be assumed; thus, a lower and higher heritability were used. This then gave rise to six estimates (two levels of heritability $x$ three measures of response) of the genetic correlation for each characteristic. The range is reported in the results. No standard errors or tests of other genetic correlations were calculated, but they are significant from zero when the correlated responses are significant.

\section{Results and Discussion}

Response in Feed Intake. Means for feed intake per day, adjusted for metabolic size, for Generations 9 through 15 are presented in Table 1. The MH - ML difference, relative to the $M C$ mean, ranged from $10.5 \%$ in Generation 10 to $20.6 \%$ in Generation 15 . The effect of selection ( $\mathrm{MH}$ vs $\mathrm{ML}$ ) was significant ( $\mathrm{P}$ $<.04$ to $P<.001$ ) in all seven generations, and there was no indication ( $P>.50$ ) of asymmetry of response. Regressions of response on generation number were as follows: upward selection, $\mathrm{MH}-\mathrm{MC}=.25 \pm .16$, downward selection, $\mathrm{ML}-\mathrm{MC}=-.56 \pm .13$, and divergence, $\mathrm{MH}-\mathrm{ML}=.82 \pm .03 \mathrm{~g} \cdot \mathrm{kg}^{-} .75 \cdot \mathrm{d}^{-1}$. Estimates of the genetic correlation with heat loss ranged between .27 and .40, assuming that heritability of feed intake per metabolic size is between .20 and .30 . 
Table 1. Means a for feed intake $\left(\mathrm{g} \cdot \mathrm{kg}^{-75} \cdot \mathrm{d}^{-1}\right)$ of male mice measured over a 21-d period between the ages of 8 and $11 \mathrm{wk}$ in three replicates of selection for high (MH) or low (ML) heat loss or control (MC)

\begin{tabular}{|c|c|c|c|c|c|c|c|c|c|c|c|c|}
\hline \multirow[b]{2}{*}{ Generation } & \multicolumn{3}{|c|}{ Replicate 1} & \multicolumn{3}{|c|}{ Replicate 2} & \multicolumn{3}{|c|}{ Replicate 3} & \multicolumn{3}{|c|}{ Average } \\
\hline & $\mathrm{MH}$ & MC & $M L$ & $\mathrm{MH}$ & $M C$ & $M L$ & $\mathrm{MH}$ & $\mathrm{MC}$ & $M L$ & $\mathrm{MH}$ & $M C$ & $M L$ \\
\hline 9 & 62.0 & 57.0 & 55.0 & 64.8 & 59.3 & 53.0 & 62.6 & 59.2 & 58.3 & 63.1 & 58.5 & 55.5 \\
\hline 10 & 60.4 & 55.3 & 55.3 & 58.0 & 54.1 & 49.3 & 55.8 & 55.5 & 52.2 & 58.1 & 55.0 & 52.3 \\
\hline 11 & 57.6 & 50.4 & 48.5 & 59.6 & 54.9 & 48.7 & 58.0 & 54.7 & 50.6 & 58.4 & 53.3 & 49.3 \\
\hline 12 & 61.0 & 53.2 & 52.2 & 62.2 & 61.3 & 51.9 & 60.3 & 58.6 & 57.6 & 61.2 & 57.7 & 53.9 \\
\hline 13 & 69.3 & 58.6 & 59.8 & 69.6 & 62.7 & 53.1 & 60.1 & 59.2 & 55.0 & 66.3 & 60.2 & 56.0 \\
\hline 14 & 61.2 & 55.2 & 51.4 & 60.1 & 55.4 & 47.0 & 57.9 & 55.0 & 49.2 & 59.7 & 55.2 & 49.2 \\
\hline 15 & 62.3 & 54.0 & 50.6 & 64.0 & 58.1 & 49.3 & 61.7 & 58.8 & 52.9 & 62.7 & 57.0 & 50.9 \\
\hline
\end{tabular}

al $n$ each generation-replicate-selection line, $n=72$ to 80 animals. Cages contained only litter mates $(n=2$ to 6$)$; there were 16 cages per generation-replicate-selection line. Individual intake was not recorded.

Variation among replicates in the magnitude of divergence, relative to the control, was consistent. Of particular interest is the divergence, hence response, observed in Replicate 3. This replicate had the least response of all three replicates within each generation; at Generation 15, the divergence in Replicate 3 was $15.0 \%$ as compared to $21.8 \%$ in Replicate 1 and $25.1 \%$ in Replicate 2. Yet, Replicate 3 was most often, across generations, the replicate having the largest divergence in heat loss. A clear explanation of this phenomenon is not apparent. But, variation in heat loss, as measured in this experiment, reflects more than simply variation in utilization of energy for maintenance.

Response in Body Mass. Means for body mass at time of heat measurement for males are given in Table 2 and at commencement of mating for females in Table 3. There was no significant divergence between $\mathrm{MH}$ and $\mathrm{ML}$, or even a noticeable trend, in body mass of males or females over the 15 generations of selection. The regression of divergence $(\mathrm{MH}-\mathrm{ML})$ on generation number was $-.04 \pm .10$ in males and $-.07 \pm .09$ in females.

Response in Body Composition. Means for fat percentage at Generations 6, 10, and 14 are shown in Table 4. At Generations 6 and 10, the $\mathrm{MH}$ and $\mathrm{MC}$ were similar in body fat percentage, and the ML were somewhat higher, although not significantly so. But at Generation 14, the mice selected for higher heat production were significantly $(P<.01)$ lower than the $M L$, and the $M C$ mice were intermediate for fat percentage. Estimates of genetic correlation with heat loss ranged from -.14 to -.08 , assuming heritability of fat percentage is between .25 and .40 .

Response in Litter Size and Its Components. Means for number born across generations are listed in Table

Table 2. Means ${ }^{\mathrm{a}}$ for male weight $\mathrm{t}^{\mathrm{b}}(\mathrm{g})$ at heat measurement in three replicates during 15 generations of selection for high (MH) or low (ML) heat loss or control (MC)

\begin{tabular}{|c|c|c|c|c|c|c|c|c|c|c|c|c|}
\hline \multirow[b]{2}{*}{ Generation } & \multicolumn{3}{|c|}{ Replicate 1} & \multicolumn{3}{|c|}{ Replicate 2} & \multicolumn{3}{|c|}{ Replicate 3} & \multicolumn{3}{|c|}{ Average } \\
\hline & $\mathrm{MH}$ & $M C$ & $M L$ & $\mathrm{MH}$ & $\mathrm{MC}$ & $M L$ & $\mathrm{MH}$ & $\mathrm{MC}$ & $M L$ & $\mathrm{MH}$ & $\mathrm{MC}$ & $M L$ \\
\hline 0 & 44.9 & 47.4 & 44.6 & 43.5 & 45.8 & 45.5 & 43.5 & 46.1 & 43.0 & 44.0 & 46.4 & 44.4 \\
\hline 1 & 31.6 & 31.9 & 31.1 & 31.2 & 32.2 & 33.5 & 32.9 & 34.9 & 33.6 & 31.9 & 33.0 & 32.7 \\
\hline 2 & 33.9 & 34.8 & 33.4 & 34.6 & 37.4 & 34.5 & 34.5 & 36.6 & 34.8 & 34.3 & 36.3 & 34.2 \\
\hline 3 & 34.9 & 35.4 & 33.6 & 21.8 & 34.5 & 33.0 & 32.6 & 36.3 & 34.1 & 33.5 & 35.4 & 33.6 \\
\hline 4 & 33.2 & 33.4 & 30.7 & 32.2 & 31.9 & 30.9 & 32.5 & 35.4 & 32.4 & 32.6 & 33.6 & 31.3 \\
\hline 5 & 34.8 & 35.8 & 31.9 & 32.3 & 33.5 & 31.4 & 32.6 & 35.4 & 33.8 & 33.2 & 34.9 & 32.4 \\
\hline 6 & 35.7 & 36.1 & 34.5 & 34.4 & 34.2 & 33.4 & 33.2 & 36.9 & 33.7 & 34.4 & 35.7 & 33.9 \\
\hline 7 & 35.5 & 34.7 & 34.2 & 34.9 & 34.6 & 33.3 & 32.5 & 35.8 & 34.8 & 34.3 & 35.0 & 34.1 \\
\hline 8 & 33.4 & 33.2 & 32.6 & 32.8 & 32.7 & 32.1 & 31.0 & 34.3 & 33.1 & 32.4 & 33.4 & 32.6 \\
\hline 9 & 33.4 & 34.5 & 32.8 & 33.9 & 34.8 & 34.0 & 33.1 & 37.4 & 36.8 & 33.5 & 35.6 & 34.5 \\
\hline 10 & 36.4 & 37.0 & 37.5 & 33.4 & 33.8 & 33.1 & 32.1 & 34.8 & 33.8 & 34.0 & 35.2 & 34.8 \\
\hline 11 & 36.1 & 35.1 & 35.5 & 34.8 & 33.9 & 33.3 & 32.9 & 36.5 & 34.8 & 34.6 & 35.2 & 34.6 \\
\hline 12 & 33.7 & 32.6 & 32.9 & 33.6 & 34.7 & 32.3 & 32.9 & 38.1 & 34.6 & 33.4 & 35.1 & 33.3 \\
\hline 13 & 36.4 & 37.4 & 37.6 & 34.1 & 35.3 & 33.7 & 31.9 & 36.2 & 33.9 & 34.1 & 36.3 & 35.1 \\
\hline 14 & 34.6 & 36.3 & 34.9 & 32.5 & 33.9 & 31.8 & 31.7 & 37.5 & 33.0 & 32.9 & 35.9 & 33.2 \\
\hline 15 & 33.2 & 34.8 & 31.7 & 31.7 & 33.0 & 31.7 & 30.9 & 35.6 & 32.2 & 31.9 & 34.5 & 31.9 \\
\hline
\end{tabular}

al $n$ each generation and replicate, $n=72$ to 80 for $M H$ and $M L$; for $M C, n=72$ to 80 for Generations 6,10 , and 15 ; otherwise $n=20$ to 35 . bMeasured between 20 and 22 wk of age in Generation 0 and between 9 and 11 wk of age for Generations 1 through 15. 
Table 3. Means ${ }^{\mathrm{a}}$ for female mating weight ${ }^{\mathrm{b}}(\mathrm{g})$ in three replicates during 15 generations of selection for high (MH) or low (ML) heat loss or control (MC)

\begin{tabular}{|c|c|c|c|c|c|c|c|c|c|c|c|c|}
\hline Generation & $\mathrm{MH}$ & $M C$ & $M L$ & $\mathrm{MH}$ & $M C$ & $M L$ & $\mathrm{MH}$ & $\mathrm{MC}$ & $M L$ & $\mathrm{MH}$ & $M C$ & $M L$ \\
\hline 0 & c & & & & & & & & & & & \\
\hline 1 & 27.1 & 26.4 & 26.9 & 26.0 & 27.3 & 27.9 & 27.3 & 28.4 & 27.2 & 26.8 & 27.4 & 27.3 \\
\hline 2 & 29.5 & 28.7 & 28.9 & 28.9 & 29.7 & 30.2 & 29.4 & 28.7 & 29.2 & 29.3 & 29.0 & 29.5 \\
\hline 3 & 30.2 & 29.3 & 29.3 & 29.7 & 29.4 & 27.3 & 26.8 & 28.9 & 28.2 & 28.9 & 29.2 & 28.3 \\
\hline 4 & 29.1 & 29.5 & 28.2 & 27.4 & 27.1 & 26.3 & 26.7 & 28.8 & 27.3 & 27.7 & 28.5 & 27.2 \\
\hline 7 & 28.9 & 26.9 & 27.6 & 29.5 & 28.1 & 28.3 & 27.4 & 29.2 & 29.4 & 28.6 & 28.0 & 28.4 \\
\hline 8 & 26.8 & 26.4 & 27.3 & 27.0 & 28.0 & 27.0 & 25.9 & 27.4 & 27.9 & 26.5 & 27.3 & 27.4 \\
\hline 9 & 27.8 & 28.4 & 30.1 & 28.0 & 27.8 & 28.0 & 27.5 & 29.9 & 31.1 & 27.8 & 28.7 & 29.7 \\
\hline 10 & 28.4 & 30.2 & 29.9 & 28.3 & 27.6 & 27.5 & 25.9 & 27.9 & 27.0 & 27.6 & 28.5 & 28.1 \\
\hline 11 & 29.1 & 28.5 & 29.1 & 28.3 & 27.1 & 27.1 & 27.1 & 29.7 & 28.0 & 28.2 & 28.4 & 28.1 \\
\hline 12 & 26.9 & 26.8 & 28.9 & 27.4 & 27.1 & 26.8 & 27.8 & 30.5 & 30.0 & 27.4 & 28.1 & 28.5 \\
\hline
\end{tabular}

a $n$ each generation and replicate, $\mathrm{n}=36$ for $\mathrm{MH}$ and $\mathrm{ML}$ and $\mathrm{n}=34$ for $\mathrm{MC}$.

${ }^{b}$ At 12 wk of age.

'Not measured in Generation 0.

5, and means for components of litter size recorded during Generation 11 or 12 are shown in Table 6. Significant differences $(\mathrm{P}<.01)$ between the $\mathrm{MH}$ and $\mathrm{ML}$ for number born ranged between 1.1 and 2.0 during Generations 10 and 15. Mean number born for MC averaged intermediate between the level of $M L$ and $\mathrm{MH}$, although the pattern was not consistent. At Generation 15, there was no indication $(P>.40)$ of asymmetry of response. Estimates of genetic correlation between number born and heat loss ranged from .15 to .29 , assuming heritability of number born in the range of .10 to .15 .

Differences among the $\mathrm{MH}, \mathrm{ML}$, and $\mathrm{MC}$ were larger when measured in the second parity (Table 6); this is probably a function of scaling because the means were also greater. Ova success was not significantly $(\mathrm{P}>.50)$ different between $\mathrm{MH}$ and $\mathrm{ML}$. Differences in ovulation rate explained the large differences in number born. The $2.1(\mathrm{P}<.02)$ difference in number of fetuses between $\mathrm{MH}$ and $\mathrm{ML}$ was due to a 2.8 difference $(P<.01)$ in ovulation rate. The MC was intermediate; hence, there was no asymmetry of response. Regressions of number of fetuses, ovulation rate, and ova success on female body mass were all positive and, because the sample of females had smaller body mass at mating for $\mathrm{MH}$ $(33.9 \mathrm{~g})$ compared to $\mathrm{ML}(35.4 \mathrm{~g})$ and $\mathrm{MC}(35.1 \mathrm{~g})$, the means adjusted for body size were even more different between $\mathrm{MH}$ and $\mathrm{ML}$ for ovulation rate and number of fetuses. Thus, differences in body size did not explain differences in litter size.

Discussion. Divergence in feed intake per unit metabolic size was $20.6 \%$, compared with divergence in total heat loss per unit metabolic size of $53.6 \%$ (Nielsen et al., 1997). Under usual circumstances and if there is no variability among animals in their ability to metabolize energy from a given feed, one would expect total heat loss to be proportional to feed intake

Table 4. Means for fat percentage at $12 \mathrm{wk}$ in three replicates measured at Generations 6,10 , and 14 of selection for high $(\mathrm{MH})$ or low (ML) heat loss or control (MC)

\begin{tabular}{|c|c|c|c|c|c|c|c|c|c|c|c|c|}
\hline \multirow[b]{2}{*}{ Generation } & \multicolumn{3}{|c|}{ Replicate 1} & \multicolumn{3}{|c|}{ Replicate 2} & \multicolumn{3}{|c|}{ Replicate 3} & \multicolumn{3}{|c|}{ Average } \\
\hline & $\mathrm{MH}$ & $\mathrm{MC}$ & $M L$ & $\mathrm{MH}$ & $\mathrm{MC}$ & $M L$ & $\mathrm{MH}$ & $\mathrm{MC}$ & $M L$ & $\mathrm{MH}$ & $\mathrm{MC}$ & $M L$ \\
\hline $6^{a}$ & 13.5 & 13.9 & 14.0 & 14.7 & 13.6 & 14.1 & 15.3 & 15.9 & 15.5 & 14.5 & 14.4 & 14.5 \\
\hline $10^{\mathrm{b}}$ & 15.3 & 16.2 & 15.9 & 14.3 & 13.5 & 14.4 & 14.3 & 14.3 & 15.5 & 14.6 & 14.7 & 15.2 \\
\hline $10^{c}$ & 13.9 & 15.1 & 14.5 & 14.3 & 12.5 & 13.2 & 13.9 & 14.4 & 14.4 & 14.0 & 14.0 & 14.0 \\
\hline $14^{d}$ & 15.8 & 16.7 & 16.7 & 15.8 & 15.8 & 16.6 & 16.3 & 16.8 & 17.3 & 16.0 & 16.4 & 16.9 \\
\hline
\end{tabular}

aMales: $n=63$ to 78 in each replicate-selection criterion class.

bMales: $n=48$ in each replicate-selection criterion class.

cFemales: $\mathrm{n}=32$ in each replicate-selection criterion class.

dMales: $n=32$ in each replicate-selection criterion class. 
Table 5. Means ${ }^{\mathrm{a}}$ for litter size at first parity in three replicates during 15 generations of selection for high (MH) or low (ML) heat loss or control (MC)

\begin{tabular}{|c|c|c|c|c|c|c|c|c|c|c|c|c|}
\hline \multirow[b]{2}{*}{ Generation } & \multicolumn{3}{|c|}{ Replicate 1} & \multicolumn{3}{|c|}{ Replicate 2} & \multicolumn{3}{|c|}{ Replicate 3} & \multicolumn{3}{|c|}{ Average } \\
\hline & $\mathrm{MH}$ & MC & $M L$ & $\mathrm{MH}$ & $\mathrm{MC}$ & $M L$ & $\mathrm{MH}$ & MC & $M L$ & $\mathrm{MH}$ & $M C$ & $M L$ \\
\hline 0 & 11.7 & 11.2 & 11.2 & 11.3 & 10.8 & 10.8 & 10.5 & 10.2 & 11.3 & 11.2 & 10.7 & 11.1 \\
\hline 1 & 10.5 & 9.3 & 10.9 & 10.4 & 10.8 & 11.1 & 9.3 & 11.1 & 10.4 & 10.0 & 10.4 & 10.8 \\
\hline 2 & 12.4 & 11.6 & 11.2 & 11.5 & 12.5 & 11.4 & 11.1 & 10.8 & 11.2 & 11.7 & 11.6 & 11.2 \\
\hline 3 & 11.6 & 10.6 & 10.6 & 11.1 & 12.1 & 9.3 & 9.3 & 10.3 & 10.9 & 10.7 & 11.0 & 10.3 \\
\hline 4 & 11.1 & 11.3 & 10.5 & 10.2 & 11.0 & 10.2 & 9.9 & 10.2 & 10.4 & 10.4 & 10.8 & 10.4 \\
\hline 5 & 11.5 & 10.9 & 9.7 & 11.8 & 10.6 & 9.4 & 11.7 & 11.0 & 10.7 & 11.7 & 10.9 & 10.0 \\
\hline 6 & 12.0 & 11.8 & 10.5 & 12.5 & 12.0 & 10.6 & 11.2 & 11.1 & 10.6 & 11.9 & 11.6 & 10.6 \\
\hline 7 & 10.7 & 10.8 & 9.5 & 11.3 & 11.0 & 9.8 & 10.0 & 11.4 & 10.9 & 10.7 & 11.1 & 10.1 \\
\hline 8 & 11.2 & 10.9 & 9.6 & 10.5 & 11.5 & 9.3 & 10.9 & 10.2 & 10.6 & 10.9 & 10.8 & 9.8 \\
\hline 9 & 12.0 & 10.7 & 10.7 & 11.5 & 11.5 & 10.3 & 11.1 & 11.5 & 11.3 & 11.5 & 11.3 & 10.8 \\
\hline 10 & 11.5 & 11.3 & 11.0 & 11.3 & 10.6 & 9.4 & 10.3 & 10.8 & 9.3 & 11.0 & 10.9 & 9.9 \\
\hline 11 & 12.4 & 10.5 & 9.9 & 11.3 & 11.4 & 9.9 & 11.3 & 10.9 & 10.2 & 11.7 & 10.9 & 10.0 \\
\hline 12 & 12.2 & 9.6 & 10.9 & 12.1 & 12.7 & 10.1 & 12.2 & 10.1 & 11.4 & 12.2 & 10.8 & 10.8 \\
\hline 13 & 12.9 & 11.6 & 11.8 & 12.4 & 12.9 & 10.1 & 11.1 & 10.6 & 10.5 & 12.1 & 11.7 & 10.8 \\
\hline 14 & 11.9 & 10.2 & 9.9 & 11.2 & 10.7 & 9.1 & 10.1 & 11.3 & 10.3 & 11.1 & 10.7 & 9.7 \\
\hline 15 & 12.3 & 10.8 & 9.5 & 12.1 & 11.3 & 9.1 & 10.8 & 11.5 & 10.4 & 11.7 & 11.2 & 9.7 \\
\hline
\end{tabular}

a $\mathrm{n}$ each generation and replicate, $\mathrm{n}=33$ to 36 for $\mathrm{MH}$ and $\mathrm{ML}$ and $\mathrm{n}=31$ to 34 for $\mathrm{MC}$.

for animals that are not growing, lactating, or storing energy in some product.

But, care must be taken in equating heat loss as measured here to energy for maintenance and to feed intake as measured in this study. Even though relatively mature males were measured for feed intake for this study and for heat loss during the selection process, the conditions for measurement of heat loss were much different than in the normal dayto-day life of the animals. Thus, the large line differences observed in heat loss were reflected in smaller magnitude with differences in energy requirements for maintenance.

Nonetheless, a divergence in feed intake of mature males of over $20 \%$ is large. The high and low responses in feed intake were symmetrical as compared to the direct responses in heat loss, which were approximately 1.5 times larger for high selection than for low. Perhaps a larger portion of the heat response for high selection is due to an increased reaction to the measuring environment mentioned above as compared to the low selection.

Kownacki et al. (1975), Kownacki and Keller (1978), and Gunsett et al. (1981), measuring lines of mice selected for higher gain or feed conversion on either ad libitum or restricted feeding, reported a reduction in either basal metabolic rate or total energy required for maintenance. Bishop and Hill (1985) reported a $13 \%$ difference in resting heat production of mature mice, measured by indirect calorimetry, between lines selected for high or low feed intake between 4 and $6 \mathrm{wk}$ of age, adjusted for 4-wk body weight.

Residual feed consumption, defined as feed consumption adjusted for average size for maintenance and mass of products (e.g., body gain, eggs, and milk) produced, has responded to selection in chickens
(Luiting et al., 1991; Bordas et al., 1992; Schulman et al., 1994). Luiting et al. (1991) reported that almost $80 \%$ of the differences between high and low selection lines were explained by activity-related differences. Heritability of residual feed consumption should be similar to heritability of maintenance requirement and heat production/loss.

Table 6. Means a for ovulation rate (OR), number of fetuses (NF) at $17 \mathrm{~d}$ of gestation, and ova success

$(\mathrm{OS}=\mathrm{NF} / \mathrm{OR})$ measured at second parity, in females from lines selected for high (MH) or low (ML) heat loss or control (MC)

\begin{tabular}{|c|c|c|c|}
\hline \multirow[b]{2}{*}{ Trait } & \multicolumn{3}{|c|}{ Selection criterion } \\
\hline & $\mathrm{MH}$ & MC & $M L$ \\
\hline \multicolumn{4}{|c|}{ Generation 11} \\
\hline \multicolumn{4}{|c|}{ Replicate 3} \\
\hline OR & 15.9 & 14.9 & 14.6 \\
\hline NF & 13.7 & 12.7 & 12.1 \\
\hline OS & .86 & .84 & .84 \\
\hline \multicolumn{4}{|c|}{ Replicate 1} \\
\hline OR & 17.8 & 15.7 & 14.3 \\
\hline NF & 15.3 & 13.2 & 12.7 \\
\hline OS & .87 & .85 & .89 \\
\hline \multicolumn{4}{|c|}{ Replicate 2} \\
\hline OR & 17.3 & 16.3 & 13.7 \\
\hline NF & 13.8 & 14.2 & 11.5 \\
\hline OS & .80 & .87 & .85 \\
\hline OR & 17.0 & 15.7 & 14.2 \\
\hline NF & 14.2 & 13.3 & 12.1 \\
\hline OS & .84 & .85 & .86 \\
\hline
\end{tabular}

al $\mathrm{n}$ each replicate-selection criterion class, $\mathrm{n}=33$ to 39 . 
Because growth is not perfectly efficient and energy is lost as new tissue is gained, we measured our selection criterion (heat loss) long after puberty at a stage when growth is slow, hoping to minimize any confounding of energy for maintenance with energy loss from growth. With no difference in body mass between high and low selection lines after 15 generations, we achieved this goal. If energy loss related to growth processes had been a large component of heat loss measured for selection and if animals had varied in their rate of growth at the time of measurement, we would have expected selection to have changed growth in the same direction as the selection applied intentionally for heat loss.

Selection for residual feed consumption in chickens (Schulman et al., 1994) produced no correlated response in body weight of laying hens. Selection for low oxygen consumption at 3 wk of age in chickens (MacLaury and J ohnson, 1972) produced birds with lower 8-wk body weight compared to selection for high oxygen consumption. Given the high growth rate of 3-wk-old chickens, we would expect differences in oxygen consumption related to differences in growth at the point of measurement of the selection criterion; thus, these results are consistent with those observed in the present study.

By later generations, the mice selected for lower heat loss had higher fat percentages than the control mice, and those selected for higher heat loss were the leanest animals. We have also measured percentage body fatness using slaughtered animals and an ether extraction procedure (data not presented) in one replicate subsequent to Generation 14, and we observed even larger differences in fat percentage between the high and low selection lines.

After 14 and 20 generations of selection in mice for high or low feed intake between 4 and 6 wk of age, corrected for 4-wk body mass, Bishop and Hill (1985) and Hastings and Hill (1989) found no change in body fatness. Likewise, Hetzel and Nicholas (1986) reported no differences in fatness between selected (under restricted or ad libitum intake for 3 to $6 \mathrm{wk}$ gain) and control mice under either feeding method even though the lines differed significantly in gain efficiency.

Pigs from a line selected for leanness were leaner and had greater heat production than animals from a fatter line (Sundstol et al., 1979). Luiting et al. (1991) reported that hens in their selection line for low residual feed consumption were fatter than hens in the high residual feed selection. These works in pigs and chickens support the findings of the present study; there seems to be an inverse relationship between heat production and body fatness. This is also supported in studies using variation produced by the obese (ob) gene in mice (Lin et al., 1979; Vander Tuig et al., 1980) from which higher maintenance per unit metabolic size was found in lean than in obese mice.
The positive correlated responses in number born represent a very undesirable relationship between energy for maintenance and number born. This same relationship was reported earlier by Brien et al. (1984). They reported a difference of 2.6 pups at first parity between high and low lines of mice selected over 10 generations for feed intake between 4 and 6 wk of age, adjusted for 4-wk body mass. Both the differences reported by Brien et al. (1984) and the differences observed here in litter size were explained by differences in ovulation rate. Why selection for higher or lower maintenance energy causes a correlated change in ovulation rate is not clear.

The results observed in mice are not consistent with the relationship observed following selection in chickens; Bordas et al. (1992) and Schulman et al. (1994) found no changes in egg number or egg weight with selection for residual feed consumption. However, across breeds (heavy meat lines and egg laying lines) of chickens, Hocking et al. (1985) found that egg laying lines had the higher feed intake per metabolic size in addition to their higher egg laying rate.

Selection to decrease energy demands for maintenance in a livestock species, if faced with the same genetic relationship between these characteristics as observed here in mice, would require attention also for number born in an index. One would expect this antagonism between traits as they relate to overall economic value in a selection index to be greater in a species in which reproductive rate is more limiting.

\section{Implications}

Selection for heat loss per unit of metabolic size in mice, either in an upward or downward direction, produces significant changes in feed intake, litter size, and body composition. If feed intake for maintenance in livestock species has similar genetic relationships with reproductive performance and body composition as heat production/loss has in mice, then a program for selection to reduce feed intake must also give attention to other performance characteristics in order not to reduce overall economic merit.

\section{Literature Cited}

Bishop, S. C., and W. G. Hill. 1985. Effects of selection for growth, body composition, and food intake in mice. III. Correlated responses: growth, body composition, food intake, and efficiency and catabolism. Genet. Res. 46:57.

Bordas, A., M. Tixier-Boichard, and P. Merat. 1992. Direct and correlated responses to divergent selection for residual food intake in Rhode Island Red laying hens. Br. Poult. Sci. 33:741.

Brien, F. D., G. L. Sharp, W. G. Hill, and A. Robertson. 1984. Effects of selection on growth, body composition, and food intake in mice. Genet. Res. 44:73.

Gunsett, F. C., D. H. Baik, J . J . Rutledge, and E. R. Hauser. 1981. Selection for feed conversion on efficiency and growth in mice. J. Anim. Sci. 52:1280. 
Hastings, I. M., and W. G. Hill. 1989. A note on the effect of different selection criteria on carcass composition in mice. Anim. Prod. 48:229.

Hetzel, D.J .S., and F. W. Nicholas. 1986. Growth, efficiency, and body composition of mice selected for postweaning weight gain on ad libitum or restricted feeding. Genet. Res. 48:101.

Hocking, P. M., J . S. Gavora, J . R. Chambers, and A. Fortin. 1985. Genetic variation in body size, composition, temperature, and feed intake in mature chickens. Poult. Sci. 64:6.

Kownacki, M., and J. Keller. 1978. The basal metabolic rate in selected and unselected mice. Genet. Pol. 19:339.

Kownacki, M., J. Keller, and E. Gebler. 1975. Selection of mice for high weight gains-its effect on the basal metabolic rate. Genet. Pol. 16:359.

Lin, P. Y., D. R. Romsos, J . G. Vander Tuig, and G. A. Leville. 1979. Maintenance and energy requirements, energy retention, and heat production of young obese (ob/ob) and lean mice fed a high-fat or a high-carbohydrate diet. J. Nutr. 109:1143.

Luiting, P., J . W. Schrama, W. van der Werf, and T.H.E. Meuwissen. 1991. Metabolic differences between White Leghorns selected for high and low residual feed consumption. In: C. Wenk and M. Boessinger ( $E$ d.) Proc. 12th Symp. on Energy Symposium. EEAP 58:384. Kartuse Ittingen, Switzerland.

MacLaury, D. W., and T. H. J ohnson. 1972. Selection for high and low oxygen consumption in chickens. Poult. Sci. 51:591.

Nielsen, M. K., L. D. J ones, B. A. Freking, and J . A. DeShazer. 1997. Divergent selection for heat loss in mice: I. Selection applied and direct response through fifteen generations. J. Anim. Sci. 75:1461.

Schulman, N., M. Tuiskula-Haavisto, L. Siitonen, and E. A. Mantysaari. 1994. Genetic variation of residual feed consumption in a selected Finnish egg-layer population. Poult. Sci. 73:1479.

Sundstol, F., N. Standal, and O. Vangen. 1979. Energy metabolism in lines of pigs selected for thickness of backfat and rate of gain. Acta Agric. Scand. 29:337.

Vander Tuig, J . C., D. R. Pomsos, and G. A. Leville. 1980. Maintenance energy requirements and energy retention of young obese (ob/ob) and lean mice housed at $33 \mathrm{C}$ and fed a highcarbohydrate or a high-fat diet. J. Nutr. 110:35. 